\title{
Sedimentary Records of Paleoredox Conditions at Relict Mudflat of Vasoj, Southern Saurashtra Coast, Gujarat, India
}

\author{
Upasana S. Banerji $^{1}$, Ravi Bhushan ${ }^{2}$ and D. M. Maurya ${ }^{1}$ \\ ${ }^{1}$ Department of Geology, M. S. University of Baroda, Vadodara 390002, India \\ ${ }^{2}$ Geosciences Division, Physical Research Laboratory, Navrangpura, Ahmedabad- 380009, India \\ Email: upasanabanerji@gmail.com
}

\begin{abstract}
Coastal lagoons form the most productive regions, in addition to receiving sediments from terrestrial and anthropogenic sources. High productivity results in oxygen deficiency thereby forming reducing conditions in the water column and sediment- water interface. The present study is an attempt to reconstruct paleoredox conditions that persisted in the paleolagoon of Vasoj village near southern Saurashtra coast of Gujarat, India. Towards this, various redox sensitive elements such as $\mathrm{Mo}, \mathrm{V}, \mathrm{Zn}, \mathrm{Ni}$ were investigated along with $\mathrm{CaCO}_{3}, \mathrm{CaO}$ and total organic carbon (TOC). The temporal variability in the concentrations suggest that anoxic conditions persisted during 4710-4000 cal yr BP, followed by euxinic conditions from 4000-3200 cal yr BP. However, post 3200 cal yr BP the water column remained oxic till 1500 cal yr BP, when the sedimentation ceased. This study further points that the euxinic conditions during 4000-3200 cal yr BP was not triggered by the intense TOC degradation but was a resultant of sea level lowering, caused by stagnation of water or reduced ventilation of water and thereby developed euxinic conditions. The results further suggest that it was after $3200 \mathrm{cal} \mathrm{yr}$ BP that the lagoon got transformed into coast/mudflat. The present study reveals the importance of redox sensitive proxies for the reconstruction of the paleolagoonal conditions of Vasoj village near southern Saurashtra coast of Gujarat, India.
\end{abstract}

Keywords: Redox elements, paleolagoon, GEOTRACES, euxinic conditions, anoxic conditions, mid-late Holocene

\section{Introduction}

The coastal lagoons experiences nutrient input from both land and sea and are usually isolated from the sea, therefore, they are highly productive and eutrophic zones along the coast (De Wit, 1999). In the present scenario, coastal lagoons experience oxygen deficient environment caused by natural as well as anthropogenic factors. In oxic environment, aerobic organism utilizes ambient dissolved oxygen (DO) and interstitial waters for the organic matter degradation. The continuous decomposition of organic matter results in oxygen depletion and the organism tends to utilize secondary oxidant sources such as nitrate, manganese oxide, iron oxides, oxyhydroxides and sulphates (Froelich et al., 1979). The continued depletion of oxygen results in anoxic conditions (No free $\mathrm{H}_{2} \mathrm{~S}$ ) and under extreme 
oxygen depleted conditions causes euxinic conditions with free $\mathrm{H}_{2} \mathrm{~S}$ in the water column. Thus, classification of the redox conditions in the sedimentary environment can be broadly divided in to four divisions as described in Table-1.

Table-1: Classification of redox conditions in a depositional environment, after (Tyson and Pearson, 1991)

\begin{tabular}{|c|c|c|c|c|}
\hline $\begin{array}{c}\text { Redox } \\
\text { conditions }\end{array}$ & Oxic & Suboxic & $\begin{array}{c}\text { Anoxic } \\
\text { (No free } \mathbf{H}_{2} \mathbf{S} \text { ) }\end{array}$ & $\begin{array}{c}\text { Euxinic } \\
\text { (With free } \mathbf{H}_{2} \mathbf{S} \text { ) }\end{array}$ \\
\hline $\begin{array}{c}\text { Oxygen } \\
\text { concentration } \\
\left(\mathrm{mlO}_{2} / \mathrm{L} \mathrm{H}_{2} \mathrm{O}\right)\end{array}$ & {$\left[\mathrm{O}_{2}\right]>2$} & $2.0>\left[\mathrm{O}_{2}\right]>0.2$ & {$\left[\mathrm{O}_{2}\right]<0.2$} & {$\left[\mathrm{O}_{2}\right]=0$} \\
\hline
\end{tabular}

The seawater comprises various trace elements either in soluble form or adsorbed onto particle whose removal from the water column to the sediment occurs via biotic or abiotic processes (Tribovillard et al., 2006). Biotic process includes consumption of trace elements by the phytoplankton which acts as micronutrients. In oxic environment, abiotic processes are limited, however, under suboxic conditions enrichment of the elements can takes place via diffusion of dissolved trace elements from the water column across sediment-water interface or via remobilization along the redox gradient with in the sediments (Tribovillard et al., 2006). Therefore, the study of trace elements distribution in sediment profile can help in deciphering the level of redox condition persisted during the deposition of the sediments.

Generally, coastal regions in tropics are inhabited by mangrove forest which accumulates large quantity of organic matter resulting into high in-situ productivity (Chmura et al., 2003), as monitored by the local hydrology, geography and topographic settings (Alongi, 2008; Perry et al., 2008). Mangrove ecosystem response towards local sea level changes and hence local sea level oscillations (Horton et al., 2007) influences the origin and amount of organic matter (Cahoon and Lynch, 1997) in the intertidal region. The mangrove ecosystem acts as a barrier against cyclones and coastal erosion and provides a nursery ground for commercially important coastal organism (crabs, prawn, fishes etc) (Selvam, 2003). In the western Indian coast, major wetlands are present in the Gujarat, wherein Gulf of Kachchh consists $77 \%$ of Gujarat mangroves, while remaining are found along Gulf of Khambhat (Singh, 2000). The present day mangroves along the Saurashtra coast from Dwarka to Rajula are mainly confined to mudflats and creeks near Dwarka, Porbandar, Mahuva, Diu, Jafarabad, Bhutharai, Pipavav Bandar and Narera Bet. These mangrove forests are sparse and scrubby and consist of mainly Avicennia sp. (Sridhar et al., 2014). However, based on palynological and geochemical evidences carried out along the southern Saurashtra coast, an extensive mangrove forest during mid-late Holocene period has been suggested with varied diversity in mangrove species which got depleted with the simultaneous sea regression (Banerji et al., 2015). The present study aims to investigate the paleo-redox conditions persisted along the southern Saurashtra coast that experienced rich and diverse mangrove forest during mid-late Holocene period (Banerji et al., 2015).

\section{Control of Redox Conditions on Trace Elements}

\section{(I) Vanadium (V)}

Vanadium in the oxic environment exists as vanadium $\left(\mathrm{V}^{+5}\right)$ in vanadate ionic species $\left(\mathrm{HVO}_{4}{ }^{2-}\right.$ and $\mathrm{H}_{2} \mathrm{VO}_{4}{ }^{-}$) (Sadiq, 1988) which under mild oxygen deficient conditions leads to 
production of vanadyl ions $\left(\mathrm{VO}^{2+}\right)$ related hydroxyl species or an insoluble hydroxides with the conversion of $\mathrm{V}\left(\mathrm{V}^{+5}\right)$ to $\mathrm{V}\left(\mathrm{V}^{+4}\right)$. In the presence of humic and fluvic acids, reduction of vanadate to vanadyl is being facilitated (Wilson and Weber, 1979). Under strong reducing conditions (i.e. in the presence of free $\mathrm{H}_{2} \mathrm{~S}$ gas), vanadium is further reduced to $\mathrm{V}$ (III) which precipitates as solid oxide $\left(\mathrm{V}_{2} \mathrm{O}_{3}\right)$ or hydroxide $\left(\mathrm{V}(\mathrm{OH})_{3}\right)$ (Breit and Wanty, 1991).

\section{(II) Molybdenum (Mo)}

Mo usually gets enriched in organic rich sediment and the transfer of molybdate $\left(\mathrm{MoO}_{4}{ }^{2-}\right)$ to the sediment water interface is being promoted via adsorption on to the humic substance (Brumsack, 1989) or particulate Fe-Mn oxyhydroxides and hence it is associated with the redox cycling of Mn and Fe (Magyar et al., 1993). Under anoxic conditions, the decay of organic matter through sulphate reducing bacteria results in the release of molybdate and Mo (VI) is reduced to Mo (V) or Mo (IV) species (Calvert and Pedersen, 1993). Under euxinic conditions, rapid uptake of Mo by authigenic sulphides (produced from the free $\mathrm{H}_{2} \mathrm{~S}$ ) can takes places (Morse and Luther, 1999).

\section{(III) Manganese (Mn)}

Under oxic conditions, Mn forms highly insoluble Mn (III) or Mn (IV) hydroxides or oxides which deposits as particulate form (Calvert and Pedersen, 1993). In case of anoxic conditions, reduction $\mathrm{Mn}$ takes place and $\mathrm{Mn}$ (II) is formed which is a soluble cation $\left(\mathrm{Mn}^{2+}\right.$ or $\mathrm{MnCl}^{+}$). As the dissolved $\mathrm{Mn}$ is not readily taken up by the organic matter or sulphide phase, it diffuses upwards till the oxic conditions is attained. In the sediments, Mn depletion may occur under reducing conditions until the fixation of manganese in carbonate mineral doesn't takes place (Hild and Brumsack, 1998).

\section{(IV) Zinc (Zn)}

In oxic environment, $\mathrm{Zn}$ is present as soluble $\mathrm{Zn}^{+2}$ cations or $\mathrm{ZnCl}^{+}$but generally it forms complexes with humic and fluvic acids (Calvert and Pedersen, 1993). With the decay of organic matter, the $\mathrm{Zn}$ is released from organometallic complexes to pore waters (Tribovillard et al., 2006). Under reducing conditions especially in the bacterial sulphate reducing conditions $\mathrm{Zn}$ may be incorporated as $\mathrm{ZnS}$ or it may also form its own sulphides (Sphalerite) (Morse and Luther, 1999; Tribovillard et al., 2006).

\section{(V) Nickel (Ni)}

With ambient oxygenated environment, $\mathrm{Ni}$ remains as soluble cation $\left(\mathrm{Ni}^{2+}\right)$ or $\mathrm{NiCl}^{+}$ but mostly it remains as soluble nickel carbonate $\left(\mathrm{NiCO}_{3}\right)$ or adsorbed on to humic and fluvic acids (Calvert and Pedersen, 1993). With decay of organic matter, Ni is released back to porewater from the organometallic complexes (Tribovillard et al., 2006). Under moderately reducing conditions in the absence of $\mathrm{Mn}$ oxides and sulphides, $\mathrm{Ni}$ gets recycled from sediments to overlying water (Tribovillard et al., 2006). But under euxinic condition in the presence of sulphides, Ni gets incorporated as insoluble NiS in to pyrite (Morse and Luther, 1999).

\section{Regional Setting}

Geologically, the southern Saurashtra comprises miliolitic limestone and coastal deposits, which includes unconsolidated beach and dune sands, tidal clays and old tidal mudflats (Verma and Mathur, 1979). The southern Saurashtra coast is marked by $40-50 \mathrm{~m}$ 
vertical cliffs of miliolite limestone. The coast is irregular and dissected further east up to Diu. Northeast of Diu Island consists of extensive tidal flats. The southern coast of this island is cliffy while beyond Diu, the coast is characterised by the presence of rocky foreshore with occasional beaches and miliolite cliffs. Along the coast of Saurashtra towards the east, locally extensive mudflats are observed near Jaffrabad. Climatically, the Saurashtra experiences a mean rainfall of $\sim 600 \mathrm{~mm}$ and the region comes under the influence of Southwest monsoon (Farooqui et al., 2013).

\section{Study Area}

The relict mudflat of Vasoj is located $\sim 10 \mathrm{~km}$ north east of Diu Island along the southern Saurashtra coast. The region is deprived of any major riverine flux however; the region receives the terrestrial contribution during summer monsoon. Geologically, the area is surrounded by biogenic carbonate (Miliolitic limestone) (Fig.1).

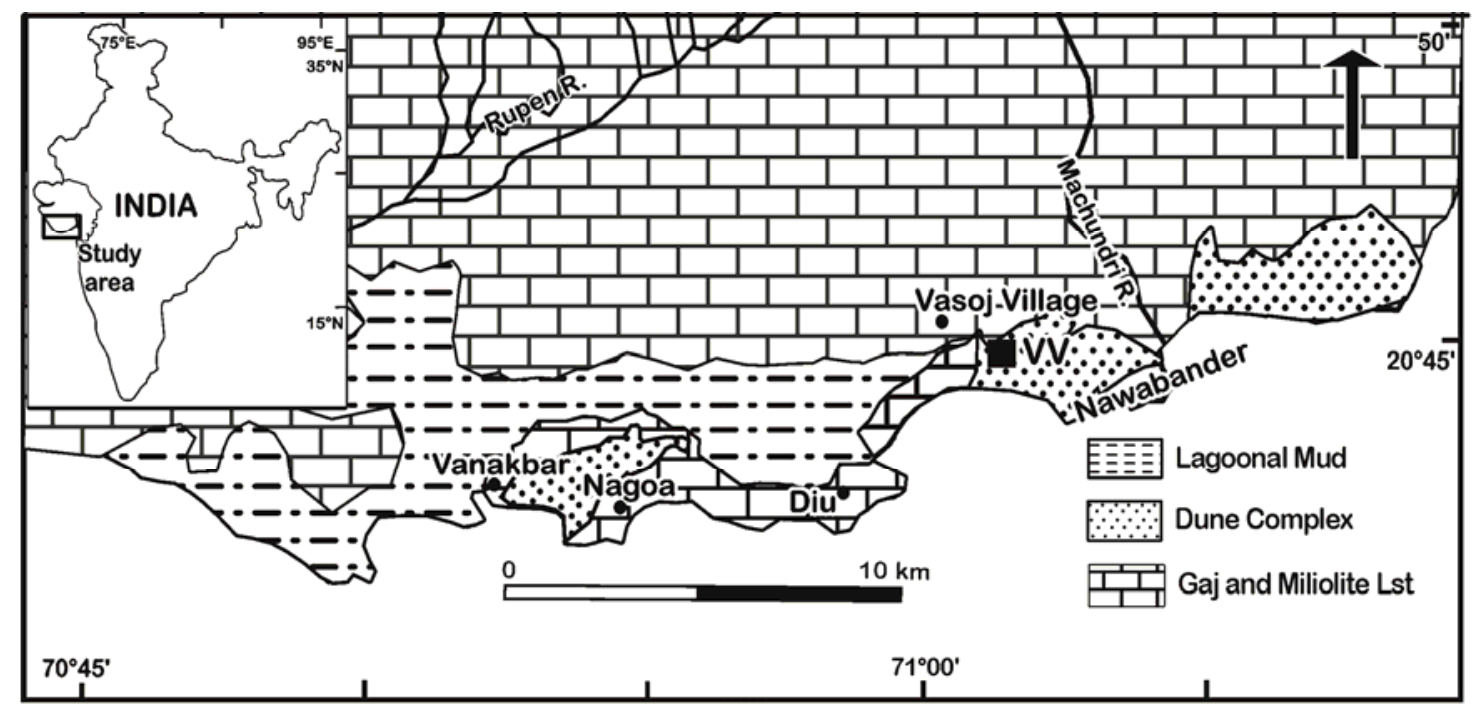

Fig. 1: Location of the pit dug at the relict mudflat of Vasoj Village marked with filled square as VV.

\section{Materials and Method}

A sediment profile of nearly $100 \mathrm{~cm}$ depth was exposed on the relict mudflat $\left(20^{\circ} 45^{\prime} 1.7^{\prime} ' \mathrm{~N} ; 7^{\circ} 0\right.$ ' $\left.14.3^{\prime} \mathrm{E}\right)$ and the samples were collected at $10 \mathrm{~cm}$ interval. The sampling procedure and the chronology have been discussed in Banerji et al. (2015). The chronology of the lithosection was established using radiocarbon $\left({ }^{14} \mathrm{C}\right)$ dating by following standard procedures (Bhushan et al., 2000) and the dates were calibrated using MARINE13 (Reimer et al., 2009; Reimer et al., 2013; Stuiver and Braziunas, 1993) with a reservoir age correction $(\Delta \mathrm{R})$ of $165 \pm 57$ incorporated in the calibrated dates (Dutta et al., 2001; Southon et al., 2002). The sedimentation rate for this section varied between $0.26-0.30 \mathrm{~mm} / \mathrm{yr}$.

The samples were dried (at $80^{\circ} \mathrm{C}$ ), crushed and homogenised with the help of agate mortar in order to avoid any metallic contamination. Nearly $0.3 \mathrm{~g}$ of bulk, dried crushed sediment samples were subjected to closed digestion (Microwave digestion system). 
Open access e-Journal

Earth Science India, eISSN: $0974-8350$

Vol. 9 (II), April, 2016, pp. 114 - 125

http://www.earthscienceindia.info/

Analytical grade reagents were used and the contamination from the time of sampling to analysis were minimised by taking due care and by running appropriate blanks for the reagents. The digested samples were analysed for $\mathrm{V}, \mathrm{Mo}, \mathrm{Ni}, \mathrm{Zn}$ and $\mathrm{Mn}$. The variation of the major elemental concentration $\left(\mathrm{Al}_{2} \mathrm{O}_{3}, \mathrm{MgO}, \mathrm{CaO}\right.$ and $\left.\mathrm{FeO}\right)$, total organic carbon (TOC) and calcium carbonate $\left(\mathrm{CaCO}_{3}\right)$ is described in Banerji, et al. (2015). The digested samples were analysed for trace elements by aspirating the sample solutions in the ICP-MS, X series II (Thermo Fisher Scientific). The accuracy of analytical procedure was accessed using certified reference standard MAG which is a fine grained gray-brown clayey mud with low carbonate content, from the Wilkinson Basin of the Gulf of Maine (Abbey, 1983; Gladney and Roelandts, 1987; Govindaraju, 1994) and NOVA deep sea clay sediment collected from N. Pacific at water depth of $5351 \mathrm{~m}$ (Amin et al., 1972).

In order to access the correlation among the geochemical parameters, Pearson's correlation coefficient for the geochemical data were calculated which included comparison of trace elemental concentration ( $\mathrm{V}, \mathrm{Mo}, \mathrm{Ni}, \mathrm{Zn}$ and $\mathrm{Mn}), \mathrm{Al}_{2} \mathrm{O}_{3}$ normalised trace elements, TOC, $\mathrm{CaCO}_{3}, \mathrm{CaO} / \mathrm{Al}_{2} \mathrm{O}_{3}$ (Table-2).

Table-2: Pearson's correlation coefficient for trace element, $\mathrm{Al}_{2} \mathrm{O}_{3}$ normalised trace elements, TOC, $\mathrm{CaCO}_{3}$ and $\mathrm{CaO} / \mathrm{Al}_{2} \mathrm{O}_{3}$ for the Vasoj relict mudflat.

\begin{tabular}{|l|l|l|l|l|l|l|l|l|l|l|l|l|l|}
\hline & $\mathbf{T O C}$ & $\mathbf{C a C O}_{3}$ & $\begin{array}{l}\mathbf{C a O} / \\
\mathbf{A l}_{2} \mathbf{O}_{3}\end{array}$ & $\mathbf{M n}$ & $\mathbf{N i}$ & $\mathbf{Z n}$ & $\mathbf{V}$ & $\mathbf{M o}$ & $\begin{array}{l}\mathbf{M n} / \\
\mathbf{A l}_{2} \mathbf{O}_{3}\end{array}$ & $\begin{array}{l}\mathbf{N i} / \\
\mathbf{A l}_{2} \mathbf{O}_{3}\end{array}$ & $\begin{array}{l}\mathbf{Z n} / \\
\mathbf{A l}_{2} \mathbf{O}_{3}\end{array}$ & $\begin{array}{l}\mathbf{V} / \\
\mathbf{A l}_{2} \mathbf{O}_{3}\end{array}$ & $\begin{array}{l}\mathbf{M o} / / \\
\mathbf{A l}_{2} \mathbf{O}_{3}\end{array}$ \\
\hline $\mathbf{T O C}$ & 1.00 & & & & & & & & & & & & \\
\hline $\mathbf{C a C O} \mathbf{O}_{3}$ & -0.41 & 1.00 & & & & & & & & & & & \\
\hline $\mathbf{C a O} / \mathbf{A l}_{2} \mathbf{O}_{3}$ & -0.41 & 0.93 & 1.00 & & & & & & & & & & \\
\hline $\mathbf{M n}$ & -0.53 & 0.89 & 0.79 & 1.00 & & & & & & & & & \\
\hline $\mathbf{N i}$ & 0.02 & -0.43 & -0.61 & -0.16 & 1.00 & & & & & & & & \\
\hline $\mathbf{Z n}$ & -0.21 & -0.21 & -0.32 & -0.16 & 0.12 & 1.00 & & & & & & & \\
\hline $\mathbf{V}$ & 0.28 & -0.85 & -0.69 & -0.85 & 0.33 & 0.28 & 1.00 & & & & & & \\
\hline $\mathbf{M o}$ & 0.42 & -0.90 & -0.72 & -0.89 & 0.12 & 0.26 & 0.92 & 1.00 & & & & & \\
\hline $\mathbf{M n} / \mathbf{A l}_{2} \mathbf{O}_{3}$ & -0.49 & 0.97 & 0.88 & 0.93 & -0.39 & -0.11 & -0.87 & -0.90 & 1.00 & & & & \\
\hline $\mathbf{N i} / \mathbf{A l}_{2} \mathbf{O}_{3}$ & -0.42 & 0.74 & 0.49 & 0.81 & 0.06 & 0.08 & -0.80 & -0.86 & 0.83 & 1.00 & & & \\
\hline $\mathbf{Z n} / \mathbf{A l}_{2} \mathbf{O}_{3}$ & -0.37 & 0.34 & 0.14 & 0.32 & -0.13 & 0.80 & -0.33 & -0.32 & 0.44 & 0.57 & 1.00 & & \\
\hline $\mathbf{V} / \mathbf{A l}_{2} \mathbf{O}_{3}$ & 0.22 & -0.84 & -0.70 & -0.74 & 0.39 & 0.40 & 0.96 & 0.91 & -0.81 & -0.69 & -0.22 & 1.00 & \\
\hline $\mathbf{M o} / \mathbf{A l}_{2} \mathbf{O}_{3}$ & 0.35 & -0.87 & -0.71 & -0.80 & 0.12 & 0.36 & 0.86 & 0.97 & -0.82 & -0.76 & -0.20 & 0.91 & 1 \\
\hline
\end{tabular}

\section{Results}

The Vasoj section is divided into three units representing distinct climatic and sea level phases. The Unit-I $(100-40 \mathrm{~cm})$ of $60 \mathrm{~cm}$ thick is represented by high organic carbon rich sediment with Turritella shells at the top $20 \mathrm{~cm}$. Unit-II $(40-20 \mathrm{~cm})$ represents marly calcareous mud following which Unit-III (20 cm-surface) represents desiccated clay. The lithology of the relict mudflat section is described in Banerji, et al. (2015).

In the relict mudflat $\mathrm{V}, \mathrm{Mo}, \mathrm{Ni}, \mathrm{Zn}$ and $\mathrm{Mn}$ concentration ranges between 102-2565 ppm, 0.4-24 ppm, 36-55 ppm, 19-124 ppm and 239-980 ppm respectively. $\mathrm{V} / \mathrm{Al}_{2} \mathrm{O}_{3}$ and $\mathrm{Mo} / \mathrm{Al}_{2} \mathrm{O}_{3}$ showed a gradual decreasing trend during 4710-1500 cal yr BP with an enhanced value between 3945-2824 cal yr $\mathrm{BP}$. However, $\mathrm{Ni} / \mathrm{Al}_{2} \mathrm{O}_{3}$ and $\mathrm{Mn} / \mathrm{Al}_{2} \mathrm{O}_{3}$ showed an 
increasing pattern with low values between 4710-3200 cal yr BP and a gradual increase after 3200 cal yr BP till 1500 cal yr BP. The variability of $\mathrm{Zn} / \mathrm{Al}_{2} \mathrm{O}_{3}$ ratio is consistent though relatively lower values between $4710-4000$ cal yr BP following a marginal increase between 4000-3200 cal yr. After 3200 cal yr BP, the $\mathrm{Zn} / \mathrm{Al}_{2} \mathrm{O}_{3}$ showed an increasing tread with fluctuating values till 1500 cal yr BP.

\section{Discussion}

The redox sensitive elements such as vanadium and molybdenum are of minimal detrital influence (Tribovillard et al., 2006). Simultaneous enrichment of Mo and V with depletion of Mn 4710-3200 cal yr BP (Fig. 2) suggests changes in the redox conditions occurred during 4710-3200 cal $\mathrm{yr}$ in the relict mudflat. The elemental concentration of $\mathrm{Mn}$ showed enrichment while Mo and $\mathrm{V}$ showed depletion in the both concentration and $\mathrm{Al}_{2} \mathrm{O}_{3}$ normalised values during 3200-1500 cal yr BP (Fig. 3).

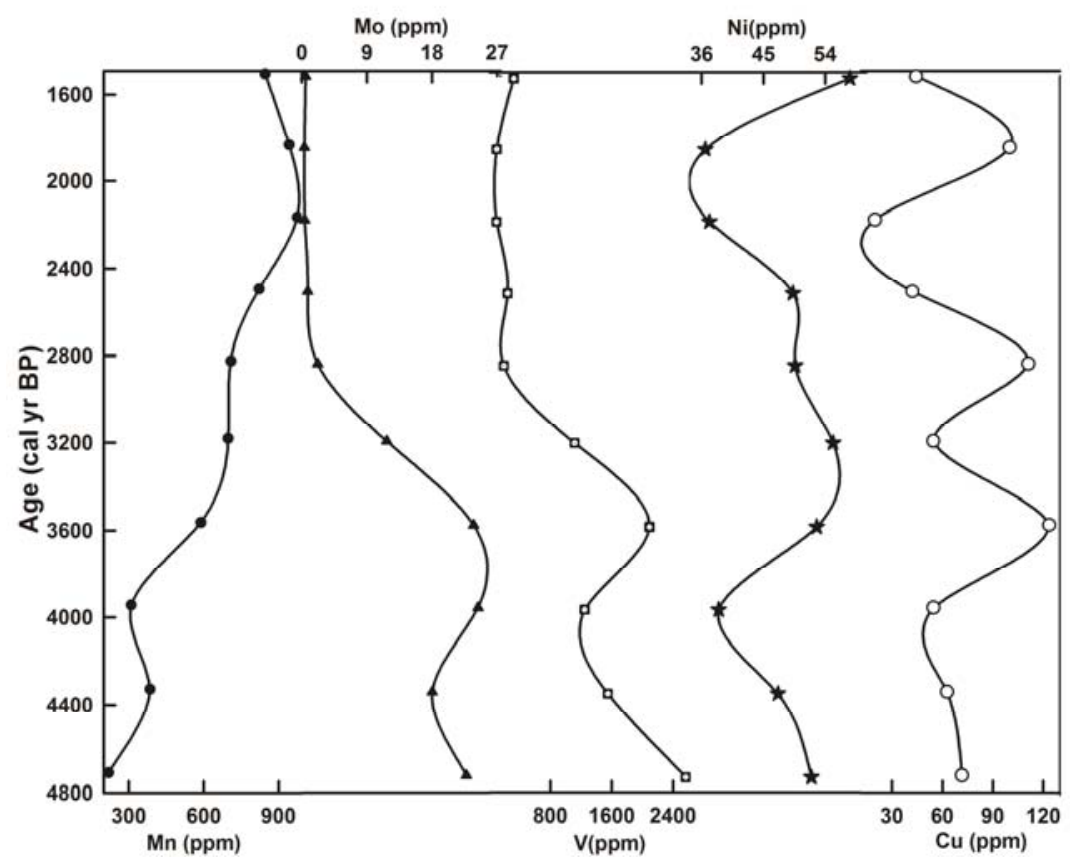

Fig. 2: Trace elemental variation for the relict mudflat section near Vasoj.

In anoxic conditions, $\mathrm{Mn}$ forms soluble $\mathrm{Mn}$ (II) which diffuses upwards and precipitates as $\mathrm{MnCO}_{3}$ or $\mathrm{Mn}-\mathrm{Ca}$ Carbonate (Calvert and Pedersen, 1993). Therefore, $\mathrm{Mn} / \mathrm{Al}_{2} \mathrm{O}_{3}$ showed a strong correlation with $\mathrm{CaCO}_{3}(0.97)$ and $\mathrm{CaO} / \mathrm{Al}_{2} \mathrm{O}_{3}$ (0.88) and a negative correlation with $\mathrm{V} / \mathrm{Al}_{2} \mathrm{O}_{3}(-0.81)$ and $\mathrm{Mo} / \mathrm{Al}_{2} \mathrm{O}_{3}(-0.82)$ (Table-2). The palynological study of the same (relict mudflat) section suggested an extensive mangrove forest with core mangrove species (Rhizophora sp., Brugeuria sp, Sonneretia sp.) in the region during 47103200 cal yr BP (Banerji et al., 2015). Mangrove forests are highly productive tropical ecosystem that plays a significant role in supporting coastal food webs and nutrient cycle. High productivity may result in ambient oxygen deficiency which in turn might create suboxic, anoxic or euxinic conditions in the region depending on the oxygen demand and supply. Therefore, TOC plays a crucial role in monitoring the ambient redox conditions. Throughout the litho section, $\mathrm{Mo} / \mathrm{Al}_{2} \mathrm{O}_{3}$ and $\mathrm{V} / \mathrm{Al}_{2} \mathrm{O}_{3}$ showed strong correlation among each other (0.88) but weak correlation with TOC (0.22) (Table-2.). 


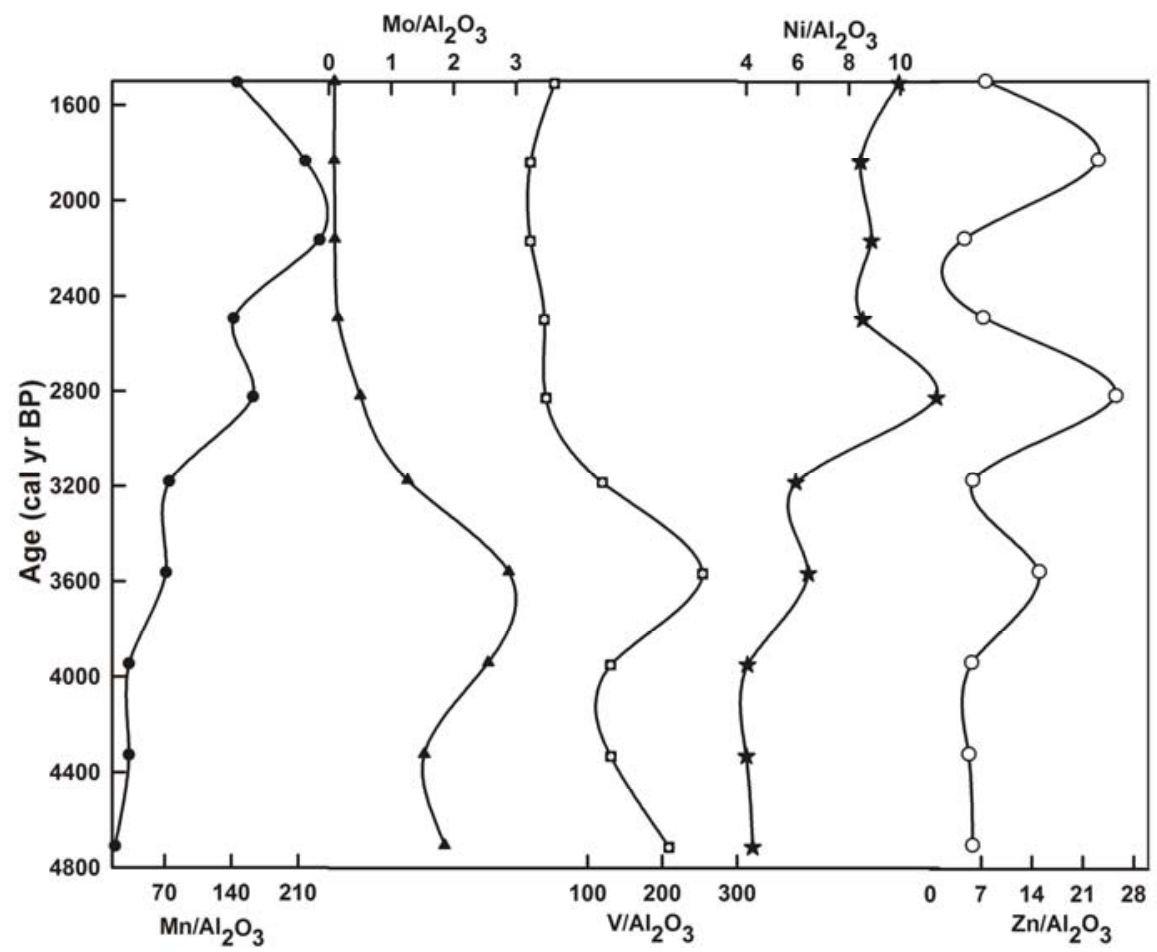

Fig. 3: $\mathrm{Al}_{2} \mathrm{O}_{3}$ normalised trace elemental variation in Vasoj section; enhanced values of $\mathrm{V} / \mathrm{Al}_{2} \mathrm{O}_{3}$ and $\mathrm{Mo} / \mathrm{Al}_{2} \mathrm{O}_{3}$ suggests euxinic conditions.

Nevertheless, during 4710-4000 cal yr BP, TOC, $\mathrm{Mo} / \mathrm{Al}_{2} \mathrm{O}_{3}$ and $\mathrm{V} / \mathrm{Al}_{2} \mathrm{O}_{3}$ show enriched concentration. Under anoxic conditions (non-sulphidic), $\mathrm{V}$ shows strong correlation with TOC suggesting that $\mathrm{V}$ being resident mainly in TOC while in euxinic conditions $\mathrm{V}$ resides predominantly in sulphidic fraction and indicates strong correlation with Mo (Algeo and Maynard, 2004). Therefore, it can be suggested that anoxic conditions persisted between 4710-4000 cal yr BP following which the lagoon experienced euxinic conditions between 4000-3200 cal yr BP. Unlike $\mathrm{Mo} / \mathrm{Al}_{2} \mathrm{O}_{3}$ and $\mathrm{V} / \mathrm{Al}_{2} \mathrm{O}_{3}, \mathrm{Ni} / \mathrm{Al}_{2} \mathrm{O}_{3}$ showed depleted values during 4710-4000 cal yr BP with a marginal enrichment observed between 4000-3200 cal yr BP, while an increasing pattern till $1500 \mathrm{cal} \mathrm{yr}$ BP has been observed after 3200 cal yr BP (Fig. 3). Though there persisted redox conditions between 4710-4000 cal yr BP, depletion of $\mathrm{Ni} / \mathrm{Al}_{2} \mathrm{O}_{3}$ suggests that $\mathrm{Ni}$ is not scavenged by settling organic particles (Tribovillard, et al., 2006). Additionally, $\mathrm{Ni} / \mathrm{Al}_{2} \mathrm{O}_{3}$ during 4710-4000 cal yr BP showed low values throughout the litho section. This is attributed to the fact that during organic matter degradation, $\mathrm{Ni}$ is released from the organometallic complexes in to the pore waters (Tribovillard et al., 2006). It also gets recycled from sediment in to the overlying waters in the absence of sulphides and Mn oxides (Tribovillard et al., 2006). Similar to $\mathrm{Mo} / \mathrm{Al}_{2} \mathrm{O}_{3}$ and $\mathrm{V} / \mathrm{Al}_{2} \mathrm{O}_{3}$, a marginal increase in the $\mathrm{Ni} / \mathrm{Al}_{2} \mathrm{O}_{3}$ during 4000-3200 cal yr BP indicates that under euxinic conditions, Ni might have formed insoluble sulphides that can be taken up by authigenic pyrite (Algeo and Maynard, 2004). However, Ni uptake is kinetically slow which in turn tends to limit its concentration in the authigenic sulphides (Algeo and Maynard, 2004; Morse and Luther, 1999; Tribovillard, et al., 2006). Therefore unlike $\mathrm{Mo} / \mathrm{Al}_{2} \mathrm{O}_{3}$ and $\mathrm{V} / \mathrm{Al}_{2} \mathrm{O}_{3}, \mathrm{Ni} / \mathrm{Al}_{2} \mathrm{O}_{3}$ does not show high values during euxinic conditions between 4000-3200 cal yr BP. Low values of $\mathrm{Zn} / \mathrm{Al}_{2} \mathrm{O}_{3}$ between $4710-4000$ cal yr BP (Fig. 3) suggests that with the decay of organic 
matter, $\mathrm{Zn}$ is released in to the pore water from the organometallic complexes. While during 4000-3200 cal yr BP, under euxinic conditions, Zn might have been incorporated as $\mathrm{ZnS}$ as solid solution phase in the pyrite or it might have formed its own sulphides (Daskalakis, 1993; Morse and Luther, 1999) which resulted in marginal increase of $\mathrm{Zn} / \mathrm{Al}_{2} \mathrm{O}_{3}$ during 4000-3200 cal yr BP.

\section{Redox conditions during 4710-1500 cal yr BP}

The Relict Mudflat of Vasoj village, southern Saurashtra coast has recorded a climatic and sea level history during 4710-1500 cal yr BP. The study suggested high sea level of nearly $2 \mathrm{~m}$ along the southern Saurashtra coast masked by $1 \mathrm{~m}$ of tectonic component (Banerji et al., 2015). Such high sea level has also being inferred based on corals and oyster beds along Diu and adjoining areas (Juyal et al., 1995). Palynological study carried out on the relict section suggested extensive mangrove forests with the presence of core mangrove species. With the simultaneous sea regression, a reduction in the mangrove forest occurred during 4710-1500 cal yr BP (Banerji et al., 2015). In the present study, high TOC with enhanced $\mathrm{Mo} / \mathrm{Al}_{2} \mathrm{O}_{3}$ and $\mathrm{V} / \mathrm{Al}_{2} \mathrm{O}_{3}$ during 4710-4000 cal yr BP is observed suggesting anoxic conditions (non-sulphidic condition) persisted in the lagoon caused by the presence of mangrove forest (Fig. 4A). However, during 4000-3200 cal yr BP, highest value $\mathrm{Mo} / \mathrm{Al}_{2} \mathrm{O}_{3}$ and $\mathrm{V} / \mathrm{Al}_{2} \mathrm{O}_{3}$ with no major change in TOC (Fig. 4B) suggests that though there persisted euxinic conditions but it was not triggered by the degradation of organic matter rather it was due to the restricted water mass renewal from the adjacent sea or due to the stagnation of water in the region (Tribovillard et al., 2006).

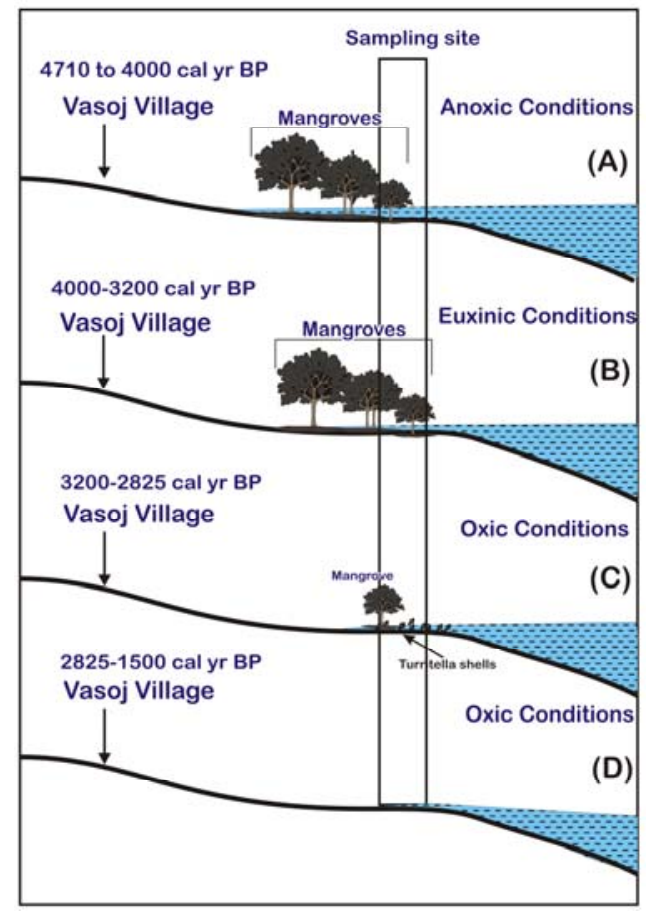

Fig. 4: Schematic view of the study area during last 4710 cal yr BP constructed based on varying redox conditions. (A) shows anoxic conditions persisted between 4710-4000 cal yr BP due to mangrove forest; (B) shows euxinic conditions existed between 4000-3200 cal yr BP due to lowering of sea in the region. (C) and (D) represents oxic conditions persisted after 3200 cal yr BP till the sedimentation in the region got ceased. 
Open access e-Journal

Earth Science India, eISSN: $0974-8350$

Vol. 9 (II), April, 2016, pp. 114 - 125

http://www.earthscienceindia.info/

As the region was experiencing a high sea level during 4710 cal yr BP with regression till 1500 cal yr BP, probably during 4000-3200 cal yr BP, there existed a phase when the region experienced last lagoonal conditions with low ventilation of water resulting in development of euxinic conditions. After $3200 \mathrm{cal} \mathrm{yr} \mathrm{BP,} \mathrm{the} \mathrm{coastal/} \mathrm{mudflat} \mathrm{environment}$ began to persist and the region experienced oxic conditions (Fig. 4C and D) till the sedimentation process ceased (till $1500 \mathrm{cal} \mathrm{yr} \mathrm{BP}$ ) in the region.

The transformation of lagoon in to mudflat due to sea regression is further supported by the presence of Turritella shells which is usually found along the coast where the sea swashes the coast in the intertidal marine environment (Desai and Patel, 2008).

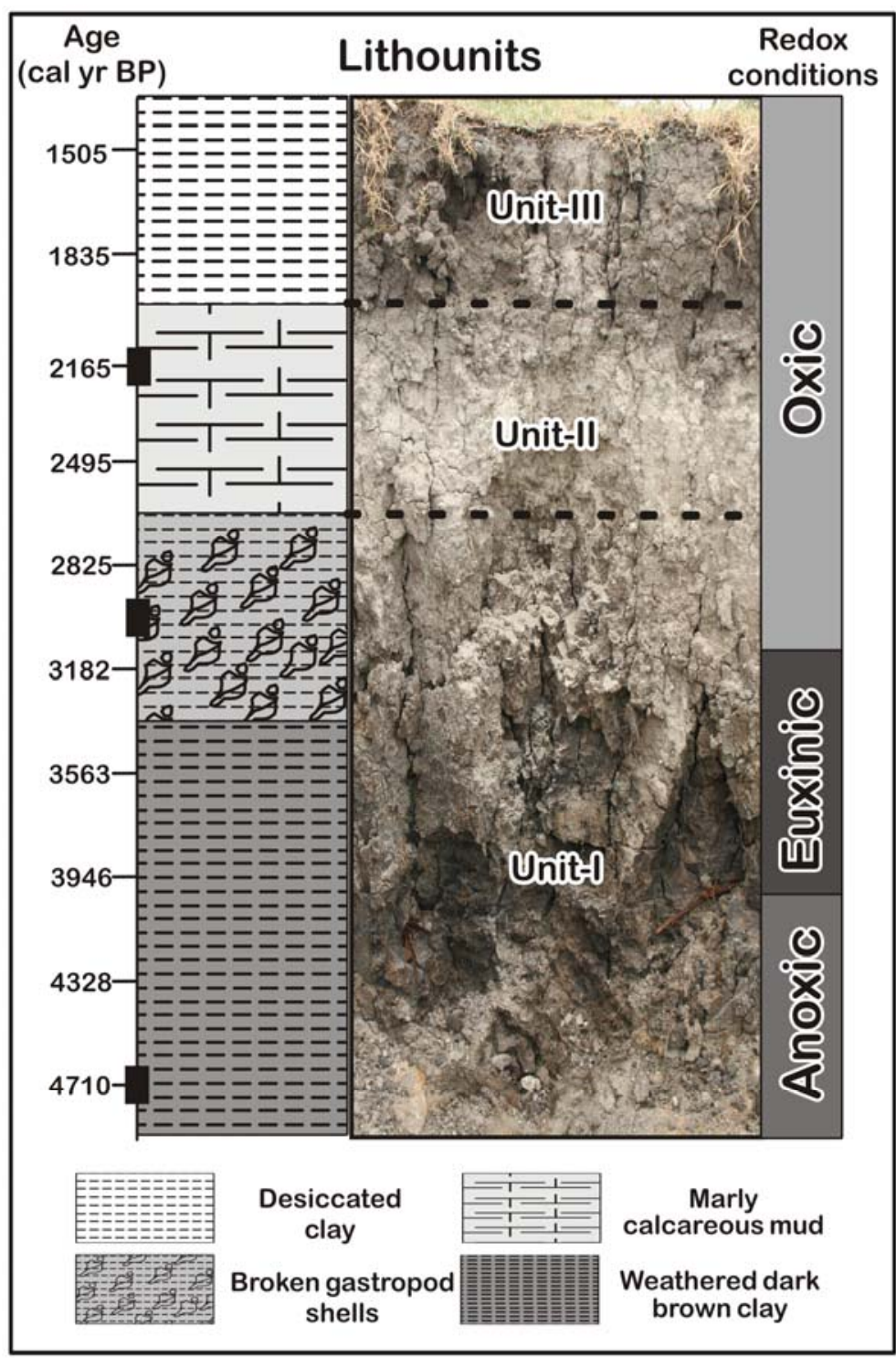

Fig. 5: Relict mudflat lithosection representing various stages of redox conditions. Filled rectangle represents the location of $\mathrm{C}-14$ dates obtained for the lithosection (modified after Banerji et al., 2015). 
Various stages of redox conditions corresponding to relict mudflat lithosection is shown in Figure 5. Based on the reconstructed redox conditions, it can be suggested that the bottom part of the weathered dark brown clay representing unit-I deposited under anoxic conditions following which euxinic conditions persisted till the broken Turritella shells were encountered at nearly 3000 cal yr BP of Unit-I (Fig.5). Later on the entire lithosection (Unit-II and Unit-III) of Vasoj experienced oxic conditions till the surface got exposed due to sea regression, resulting in termination of sediment deposition in the region.

\section{Conclusion}

The present study attempts to decipher the paleo-redox conditions of Vasoj village near southern Saurashtra coast of Gujarat, India during 4710-1500 cal yr BP. The study is in continuation and accordance with the previous study carried out at the relict mudflat of Vasoj village which suggested marginally high sea level with an extensive mangrove forest of core mangrove species in the region (Banerji et al., 2015). Based on redox sensitive elements and their behaviour, the present study suggested that the region experienced anoxic conditions between 4710-4000 cal yr BP, following which euxinic conditions persisted during 4000-3200 cal yr BP. Thereafter, oxic conditions existed till the sedimentation process ceased with the sea regression. Additionally, the study also reveals that the euxinic conditions was not a result of organic matter degradation, rather it was caused due to the low ventilation of water or due to stagnation of water from the adjacent sea caused by regressive phase of the sea in the region.

Acknowledgement: We are thankful for the support of Ministry of Earth Sciences, Govt. of India under GEOTRACES Project. We thank Dr. Navin Juyal, Mr. Balaji D. and Mr. J.P. Bhavsar for their kind help and support during the fieldwork. We are grateful to Prof. J.S. Ray for his support and help during trace element measurements.

\section{References}

Abbey, S. (1983) Studies in "Standard Samples" of Silicate Rocks and Minerals 1969-1982. Canadian Geological Survey Paper, v. 83-15, pp. 114.

Algeo, T.J. and Maynard, J.B. (2004) Trace-element behavior and redox facies in core shales of Upper Pennsylvanian Kansas-type cyclothems. Chemical Geology, v. 206 (3), pp. 289-318.

Alongi, D.M. (2008) Mangrove forests: resilience, protection from tsunamis, and responses to global climate change. Estuarine, Coastal and Shelf Science, v. 76 (1), pp. 1-13.

Amin, B., Likhite, S., Radhakrishnamurty, C. and Somayajulu, B. (1972) Susceptibility stratigraphy and paleomagnetism of some deep Pacific Ocean cores. Deep Sea Research and Oceanographic Abstracts, 19, pp. 249-252. Elsevier.

Banerji, U.S., Pandey, S., Bhushan, R. and Juyal, N. (2015) Mid-Holocene climate and land-sea interaction along the southern coast of Saurashtra, western India. J. Asian Earth Sciences, v. 111, pp. 428-439.

Bhushan, R., Somayajulu, B.L.K., Chakraborty, S. and Krishnaswami, S. (2000) Radiocarbon in the Arabian Sea water column: Temporal variations in bomb ${ }^{14} \mathrm{C}$ inventory since the GEOSECS and $\mathrm{CO}_{2}$ air-sea exchange rates. J. Geophysical Research: Oceans, v. 105 (C6), pp. 14273-14282.

Breit, G.N. and Wanty, R.B. (1991) Vanadium accumulation in carbonaceous rocks: a review of geochemical controls during deposition and diagenesis. Chemical Geology, v. 91 (2), pp. 83-97.

Brumsack, H.J. (1989) Geochemistry of recent TOC-rich sediments from the Gulf of California and the Black Sea. Geologische Rundschau, v. 78 (3), pp. 851-882.

Cahoon, D.R. and Lynch, J.C. (1997) Vertical accretion and shallow subsidence in a mangrove forest of southwestern Florida, USA. Mangroves and Salt Marshes, v. 1 (3), pp. 173-186.

Calvert, S. and Pedersen, T. (1993) Geochemistry of recent oxic and anoxic marine sediments: implications for the geological record. Marine geology, v. 113 (1), pp. 67-88.

Chmura, G.L., Anisfeld, S.C., Cahoon, D.R. and Lynch, J.C. (2003) Global carbon sequestration in tidal, saline wetland soils. Global biogeochemical cycles, v. 17 (4), pp. 22 1-22 12. 
Open access e-Journal

Earth Science India, eISSN: $0974-8350$

Vol. 9 (II), April, 2016, pp. 114 - 125

http://www.earthscienceindia.info/

Daskalakis, K.D. (1993) The solubility of sphalerite $(\mathrm{ZnS})$ in sulfidic solutions at $25^{\circ} \mathrm{C}$ and 1 atm pressure. Geochimica et Cosmochimica Acta, v. 57 (20), pp. 4923-4931.

De Wit, R. (1999) The Role of Buffering capacities in Stabilising coastal lagoon ecosystems. EaC-. ELOISE. ENV4-CT96-0218, 2 volumes.

Desai, B.G. and Patel, S.J. (2008) Trace fossil assemblages (Ichnocoenoses) of the tectonically uplifted Holocene shorelines, Kachchh, Western India. Journal geological Society of Indian, v. 71, pp. 527-540.

Dutta, K., Bhushan, R. and Somayajulu, B. (2001) R correction values for the northern Indian Ocean. Radiocarbon, v. 43 (2A), pp. 483-488.

Farooqui, A., Gaur, A.S. and Prasad, V. (2013) Climate, vegetation and ecology during Harappan period: excavations at Kanjetar and Kaj, mid-Saurashtra coast, Gujarat. Journal of Archaeological Science, v. 40 (6), pp. 2631-2647.

Froelich, P.N., Klinkhammer, G., Bender, M.a.a., Luedtke, N., Heath, G.R., Cullen, D., Dauphin, P., Hammond, D., Hartman, B. and Maynard, V. (1979) Early oxidation of organic matter in pelagic sediments of the eastern equatorial Atlantic: suboxic diagenesis. Geochimica et Cosmochimica Acta, v. 43 (7), pp. 1075-1090

Gladney, E.S. and Roelandts, I. (1987) Compilation of Elemental Concentration Data for USGSBHVO-1, MAG-1, QLO-1, RGM-1, SCo-1, SDC-1, SGR-1, and STM-1. Geostandards Newsletter, v. 12, pp. 253-362.

Govindaraju, K. (1994) 1994 Compilation of Working Values and Descriptions for 383 Geostandards. Geostandards Newsletter, v. 18, p. 1-158.

Hild, E. and Brumsack, H.J. (1998) Major and minor element geochemistry of Lower Aptian sediments from the NW German Basin (core Hohenegglesen KB 40). Cretaceous Research, v. 19 (5), pp. 615-633.

Horton, B.P., Zong, Y., Hillier, C. and Engelhart, S. (2007) Diatoms from Indonesian mangroves and their suitability as sea-level indicators for tropical environments. Marine Micropaleontology, v. 63 (3), pp. 155-168.

Juyal, N., Pant, R.K., Bhushan, R. and Somayajulu, B.L.K. (1995) Radiometric dating of late Quaternary sea levels of the Saurashtra coast, Western India: An experiment with oyster and clam shells. Geol. Soci. Ind. Memoir, v. 32, pp. 372-379.

Magyar, B., Moor, H. and Sigg, L. (1993) Vertical distribution and transport of molybdenum in a lake with a seasonally anoxic hypolimnion. Limnology and oceanography, v. 38, pp. 521-521.

Morse, J. and Luther, G. (1999) Chemical influences on trace metal-sulfide interactions in anoxic sediments. Geochimica et Cosmochimica Acta, v. 63 (19), pp. 3373-3378.

Perry, C.T., Berkeley, A. and Smithers, S.G. (2008) Microfacies characteristics of a tropical, mangrove-fringed shoreline, Cleveland Bay, Queensland, Australia: sedimentary and taphonomic controls on mangrove facies development. Journal of Sedimentary Research, v. 78 (2), 77-97.

Reimer, P.J., Baillie, M.G.L., Bard, E., Bayliss, A., Beck, J.W., Blackwell, P.G., Ramsey, C.B., Buck, C.E., Burr, G.S., Edwards, R.L., Friedrich, M., Grootes, P.M., Guilderson, T.P., Hajdas, I., Heaton, T.J., Hogg, A.G., Hughen, K.A., Kaiser, K.F., Kromer, B., McCormac, F.G., Manning, S.W., Reimer, R.W., Richards, D.A., Southon, J.R., Talamo, S., Turney, C.S.M., van der Plicht, J. and Weyhenmeyer, C.E. (2009) IntCa109 and Marine09 Radiocarbon Age Calibration Curves, 0-50,000 Years cal BP. Radiocarbon, v. 51 (4), pp. 1111-1150.

Reimer, P.J., Bard, E., Bayliss, A., Beck, J.W., Blackwell, P.G., Bronk Ramsey, C., Buck, C.E., Cheng, H., Edwards, R.L., Friedrich, M., Grootes, P.M., Guilderson, T.P., Haflidason, H., Hajdas, I., Hatté, C., Heaton, T.J., Hoffmann, D.L., Hogg, A.G., Hughen, K.A., Kaiser, K.F., Kromer, B., Manning, S.W., Niu, M., Reimer, R.W., Richards, D.A., Scott, E.M., Southon, J.R., Staff, R.A., Turney, C.S.M. and van der Plicht, J. (2013) IntCal13 and Marine13 Radiocarbon Age Calibration Curves 0-50,000 Years cal BP. Radiocarbon, v. 55 (4), pp. 1869-1887.

Sadiq, M. (1988) Thermodynamic solubility relationships of inorganic vanadium in the marine environment. Marine Chemistry, v. 23 (1), 87-96.

Selvam, V. (2003) Environmental classification of mangrove wetlands of India. Current Science, v. 84 (6), pp. 757-765.

Singh, H.S. (2000) Mangroves of Gujarat. Gujarat Ecological Education and Research Foundation, Gandhinagar.

Southon, J., Kashgarian, M., Fontugne, M., Metivier, B. and Yim, W. (2002) Marine reservoir corrections for the Indian Ocean and Southeast Asia. Radiocarbon, v. 44, pp. 167-180.

Sridhar, A., Chamyal, L.S. and Patel, M. (2014) Palaeoflood record of high-magnitude events during historical time in the Sabarmati River, Gujarat. Current Science, v. 107 (4), pp. 675-678. 
Stuiver, M. and Braziunas, T.F. (1993) Modeling atmospheric (super 14) C influences and (super 14) C ages of marine samples to 10,000 BC. Radiocarbon, v. 35, pp. 137-137.

Tribovillard, N., Algeo, T.J., Lyons, T. and Riboulleau, A. (2006) Trace metals as paleoredox and paleoproductivity proxies: An update. Chemical Geology, v. 232 (1-2), pp. 12-32.

Tyson, R. and Pearson, T. (1991) Modern and ancient continental shelf anoxia: an overview. Geological Society, London, Special Publications, v. 58 (1), pp. 1-24.

Verma, K.K. and Mathur, U.B. (1979) Report on the studies on miliolite limestones and associated tertiary and quaternary deposits of Delvada coast, Junagarh district, Gujarat. Progress report for the field seasons 1973-74 \& 75-76. Geological Survey of India, Western Region, www.portal.gsi.gov.in.

Wilson, S.A. and Weber, J.H. (1979) An EPR study of the reduction of vanadium (V) to vanadium (IV) by fulvic acid. Chemical Geology, v. 26 (3), pp. 345-354.

(Received: 22.02.2016; Accepted: 18.04.2016) 